$10 \mid 2021$

Intelligence artificielle, pratiques sociales et politiques publiques

\title{
AI in Africa : Framing AI through an African Lens
}

IA en África : enmarcando la IA a través de una lente africana

L'IA en Afrique : encadrer l'IA à travers une optique africaine

\section{Angeline Wairegi, Melissa Omino and Isaac Rutenberg}

\section{CpenEdition}

\section{Journals}

\section{Electronic version}

URL: https://journals.openedition.org/ctd/4775

DOI: $10.4000 /$ ctd. 4775

ISSN: 2491-1437

\section{Publisher}

Chaire Unesco Pratiques émergentes en technologies et communication pour le développement

Printed version

ISBN: 2491-1437

Electronic reference

Angeline Wairegi, Melissa Omino and Isaac Rutenberg, "Al in Africa : Framing Al through an African Lens", Communication, technologies et développement [Online], 10 | 2021, Online since 20 May 2020, connection on 27 May 2021. URL: http://journals.openedition.org/ctd/4775 ; DOl: https://doi.org/ $10.4000 /$ ctd. 4775

This text was automatically generated on 27 May 2021.

Communication, technologies et développement 


\title{
AI in Africa : Framing AI through an African Lens
}

\author{
IA en África: enmarcando la IA a través de una lente africana \\ L'IA en Afrique : encadrer l'IA à travers une optique africaine
}

Angeline Wairegi, Melissa Omino and Isaac Rutenberg

\section{Introduction}

1 Artificial intelligence (AI) is impacting every sector - finance, national security, health care, criminal justice, transportation, smart cities, etc. - of private and public life (West, 2018). One of the great advantages of AI technology, and a reason for its rapid adoption in parts of Asia and North America, is its capacity to engender economic development. Artificial intelligence technologies, fueled by increased productivity ( $\$ 6.6$ trillion) and by consumption effects ( $\$ 9.1$ trillion), could increase global GDP by $\$ 15.7$ trillion (14 \%) by 2030 - with an estimated increase of $\$ 7$ trillion in China, $\$ 3.7$ trillion in North America, \$1.8 trillion in Northern Europe, \$ 1.2 trillion for Africa and Oceania, \$ 0.9 trillion in the rest of Asia outside of China, $\$ 0.7$ trillion in Southern Europe, and $\$ 0.5$ trillion in Latin America (PriceWaterhouseCoopers, 2017). With such future projections, it is essential that Africa find ways to leverage AI to take advantage of the many benefits it promises.

2 Africa is a continent in flux. It is the second most populous continent after Asia and the population is young - a median age of less than 25 years (Dews, 2019); this translates to a large proportion of young adults of working-age (over 40 percent), a rapidly growing school age population, and high rates of workforce growth (Cincotta, 2010; Mubila, 2012). This has been cited as a factor in the high levels of unemployment and political instability on the continent (Mubila, 2012). Many of the countries on the continent also suffer from a significant urban - rural gap, i.e., stark differences in living standards, measured by income, consumption, or various nonmonetary aspects of life between the rural and urban regions (Lagakos, 2020, pp. 174-192). Due to this, Africa, and especially Sub-Saharan Africa, is experiencing an unprecedented rate of urban growth. This 
migration from rural to urban areas presents daunting challenges for development, in terms of land access, infrastructure and basic service needs (Mubila, 2012; Lagakos, 2020 , pp. 174-192). Finally, Africa's fairly recent adoption of modern information and communication technologies (ICT) is rapidly changing every aspect of life on the continent ; it is impacting the economic progress, or lack thereof, of poor workers in many of its countries (Goldberg, 2015; Harrison, McLaren, \& McMillan, 2011, pp. 261 289), improving levels of democracy and digital politics (Evans, 2019, pp. 169 - 191) and resulting in innovative tech-based solutions to some of the most pressing problems on the continent (Adenle, Wedig, \& Azadi, 2019, p. 101143; Kusakana, 2014, pp. 370 - 379; Udomkun, et al., 2017, pp. 127 - 138; Traxler \& Leach, 2006, pp. 98 -102).

This paper argues that as a consequence of Africa's geographical, cultural and political landscape the 4th industrial revolution will unfold differently on the continent relative to the rest of the world. As such the motivations, stakeholders, and impact of AI technology on the continent are best analyzed and framed through an African lens. There is also concern that without an objective assessment of AI on the continent its benefits will not be shared equally; in fact, its adoption may negatively impact some in the community. Unchecked, AI undoubtedly reproduces existing power dynamics. An example of this is the much discussed and documented instances of AI gender bias. A partial list includes : gender bias from Amazon's Alexa and Apple's Siri (Bolukbasi, 2016), gender bias in computer vision systems (Buolamwini \& Gebru, 2018), gender bias in recruiting engines (Dastin, 2018), racial bias in criminology software (Larson, Mattu, Kirchner, \& Angwin, 2016), racial bias in healthcare AI platforms (Obermeyer, Powers, Vogeli, \& Mullainathan, 2019), amongst others. Concerns of job loss from automation of industrial processes have also been raised, as well as fears from activists that AI surveillance systems may be used to repress citizens (Feldstein, 2019). It is essential, therefore, that perspectives that have been hitherto ignored are included in the decision making process for AI development, adoption and policy. The first step in this process is the creation of an AI stakeholder framework to characterize the parties involved in the AI sphere. Section II of this paper gives an overview of the methodology utilized in this study; section III gives a comprehensive description of the AI stakeholder framework and, finally, section IV outlines future work to be done.

\section{Methods}

4 This study was conducted by accessing and analyzing open-access material, including news articles, websites, corporate documents, academic articles, NGO reports, expert submissions, and other public sources, to determine the AI technology and AI stakeholders present in Africa. Sources were categorized into tiered levels of reliability and accuracy. First-tier sources included major print and news magazine outlets (such as the New York Times, Economist, Financial Times, and Wall Street Journal). Secondtier sources included major national media outlets, and third-tier sources consisted largely of web articles and blog posts. This information was supplemented, when possible, with primary data. 


\section{African Al Stakeholders Framework}

5 There is need for an objective assessment - one not relying on dominant Western voices - of the current AI landscape (technology, data infrastructure, developers, labor force, consumer base, laws, etc. relevant to AI) on the African continent. To that end, we have created a novel theoretical framework to characterize its stakeholders.

Characterization will aide in identifying disparities in power, information asymmetries and intersecting interests amongst the stakeholders. The relationships and power dynamics between these groups govern : (i) the distribution of resources, (ii) development of AI technology, (iii) attitudes toward AI, (iv) creation of legal and regulatory frameworks, and (v) advocacy for communities impacted by the adoption of AI. Ultimately, understanding these interdependent relationships will help in ensuring that the AI ecosystem developed on the continent is equitable and beneficial to all.

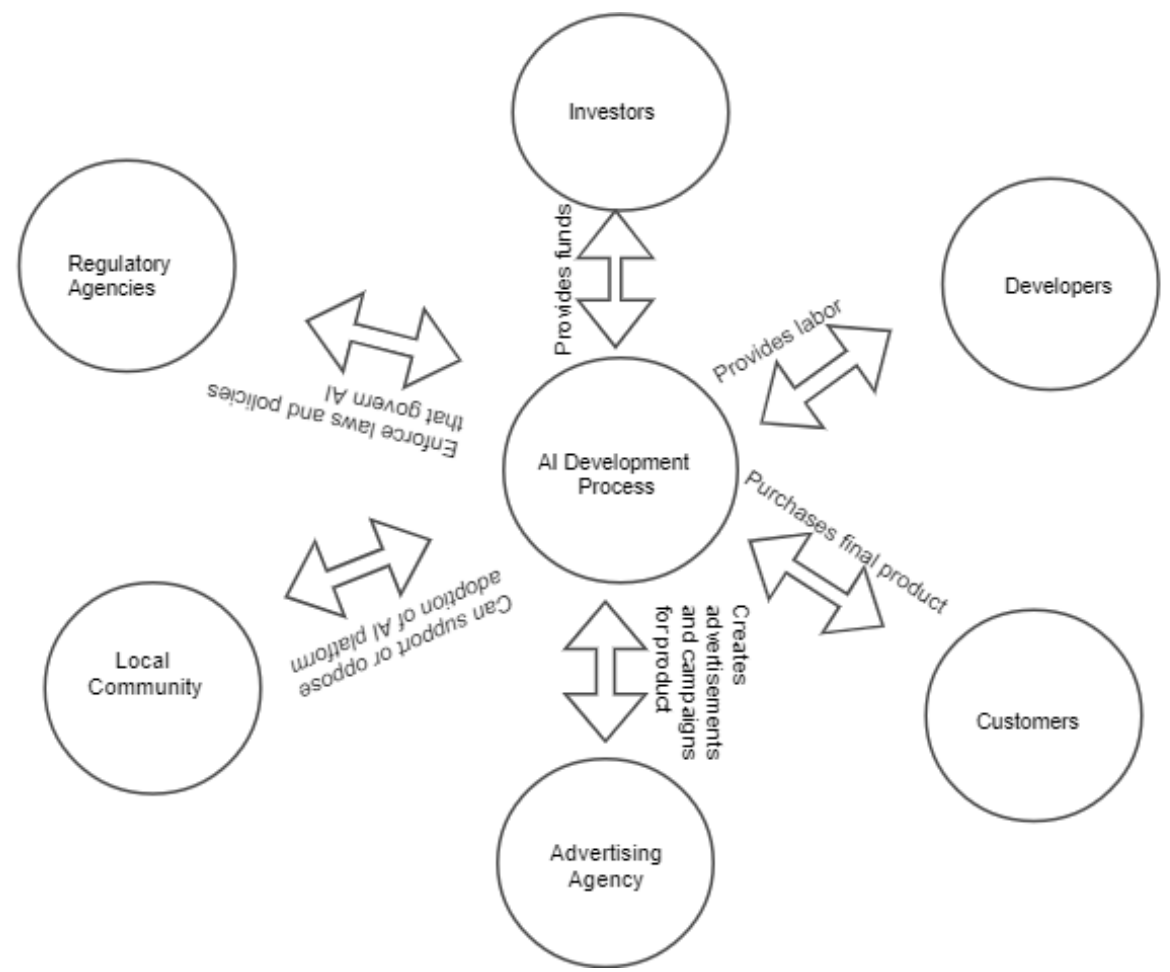

Figure 1 : An example of the stakeholders involved in the development of an Al platform. Each group contributes, directly or indirectly, resources (labor, time, funds, equipment, feedback, etc.) to the creation of the platform and are impacted, however nominally, by the final product. They also impact each other within the ecosystem.

The African AI ecosystem, in this context, refers to the groups, and their interdependent relationships, who impact and are impacted by AI. We refer to these groups as stakeholders. We use the term to include :

"those groups without whose support the organization would cease to exist" (Standford Research Center, 1963);

"any group or individual who can affect or is affected by the achievement of the organization's objectives" (Freeman R. , 1984, p. 46) ;

"participants in the human process of joint value creation" (Freeman R. , 1994, p. 411); 
11 resources, or output or is affected by that output" (Bryson, 1995, p. 27)

12 success" (Cambridge Dictionary);

13 "individuals and other entities that add value to the organization, or are otherwise interested in, or affected by, the activities of the organization" (I.O.F Standardization, 2009) ;

14 "a person, a group or an organization that has an interest in, or can affect, be affected by, or perceive itself to be affected by, any aspect of the project" (I.O.F Standardization, 2012)

15 Each of above definitions may describe a stakeholder in the African AI ecosystem. To identify the stakeholders, we envision the AI ecosystem as a corporation and the environment encompassing it and utilize stakeholder theory, widely used to describe and analyse the relationship between corporations and society (Buchholz \& Rosenthal, 2005), to identify and characterize the parties within it. Buchholz and Rosenthal's relational view of the corporation and its stakeholder eschews the individualism embedded in most stakeholder theories making it well suited for an African perspective and culture that prizes co-existence, collectiveness and consensus. Rather than view stakeholder as isolatable units with well-defined boundaries that are separate from their surroundings and independent to the identity of a corporation, stakeholders are seen as intrinsically connected with each other in a web of relationships that are integral to any proper understanding of the system (Buchholz \& Rosenthal, 2005).

In developing this framework, we utilized the normative stakeholder theory. The stakeholder model is based on the view of the corporation as a social entity that has responsibility (and accountability) to a variety of stakeholders, in its widest sense (Freeman \& Reed, 1983). The application of stakeholder theory is affected by the context in which it is deployed. In this bourgeoning AI ecosystem, it is important to take an inclusive approach (consider all relevant stakeholder, not only those deemed fiscally important) to its governance, and identify the obligations and responsibilities of stakeholder or organizational groups rather than focusing on individual companies (similar to Buchholz and Rosenthal's work which champions the collective over the individual). The normative stakeholder theory allows for this. The exclusion of any stakeholders in decision-making would also run contrary to the African principles of collectiveness. The normative stakeholder theory is well suited for identifying parties of interest in a system where moral and ethical considerations are a key factor in decision making. It enables identification of a range of potential obligations that corporations operating in developing countries may take on that may not be applicable to corporations in developed countries, and focus on the obligations of a groups of stakeholders rather than individual entities in specific situations (Reed, 2002). By outlining responsibilities of each stakeholder group, the normative stakeholder theory allows for analysis of existing public policy, and creation of new policy, that encompasses and accounts for all stakeholders in the system. This is critical to the African AI ecosystem where innovation is far outpacing legislation.

This theory is normatively based on the evolving theory of property (Donaldson \& Preston, 1995, pp. 65-91) - the notion that property rights are embedded in human rights which means that the interests of others (who can be viewed as non-owner stakeholders) must also be considered. It has been utilised, from a critical theory 
perspective (Reed, 1999, pp. 453 - 483), to argue that corporations in developing countries face increased responsibilities due to the different economic, political, and socio-cultural circumstances under which corporations have to operate, and several key normative principles which typically do not come into play in the context of developed countries (Reed, 2002, pp. 167-207).

The guiding principle of normative stakeholder theory is that all stakeholders have intrinsic moral worth or value (Donaldson \& Preston, 1995, pp. 65 - 91). This theory categorizes stakeholders into different groups based on the type of normative claims claims on how things ought to be - they can make on the system centered on three basic stakes. These basic stakes, each of which can further be defined in terms of the responsibilities they imply to particular stakeholder groups, are fair economic opportunity, political equality, and authenticity (Reed, 2002, pp. 166 - 207). Fair economic opportunity refers to the ability of persons to procure their basic material needs and better their economic prospects ; political equality refers to the capacity of people to influence norms and policies of public interaction; and authenticity is the ability for people to develop and sustain individual and communal identities (Reed, 2002, pp. 166 - 207). These claims are appealing to established cultural mores and values and not on fiduciary obligations to company stakeholders, i.e. these are based on normative expectations that hold the view that stakeholder holistic well-being be the end goal and not the instrumental approach that mainly considers the financial wellbeing of stakeholders. Instrumental approaches look to the effects of stakeholders' management on corporate performance while normative approaches are concerned with the reasons why stakeholders' interests should be taken into account (Wijnberg, 2000).

Normative stakeholder theory is also particularly well suited for use in fields of emerging technology as it can be applied in two ways : (i) to determine the responsibilities of management in the context of existing laws or institutions, or (ii) to determine the possible need for change to existing laws and institutions (Hendry, 2001, pp. 159-176). This is pertinent as the creation of laws to govern new technologies often lags behind their development, as is the case of AI in Africa.

Applying the theory to the AI ecosystem allows the delineation of tiers of stakeholders. It is important to note that the tiers : primary, secondary, and tertiary do not denote importance, power, legitimacy, or urgency of the stakeholders to the ecosystem only relational distance to the development and adoption process.

21 First, stakeholders are categorized in terms of their influence on the AI development process and the impact of the AI product on them. 


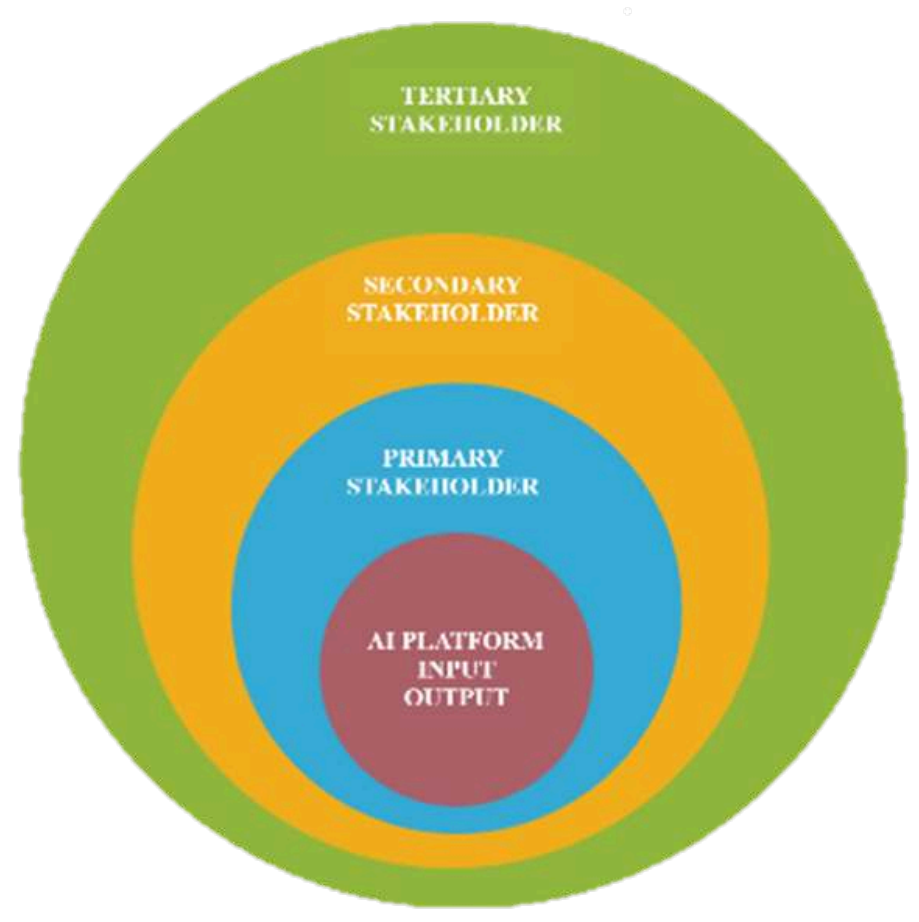

Figure 2 : Stakeholders characterized by their impact to and from the Al project. Primary stakeholders are essential to the Al company ; have direct input and are directly impacted by the company's Al products. Secondary stakeholders only have indirect input and are indirectly impacted by the Al technology and tertiary stakeholders even less so.

Stakeholders with direct input in the AI development and adoption process and who are impacted directly by the project are defined as primary stakeholders. Examples include : investors, developers (e.g. code writers, data analysts, etc.), company owners, customers, and vendors. Parties who have indirect influence in the AI development and adoption process and indirectly experience effects of the AI product, positive or negative, are characterized as secondary stakeholders. Regulatory agencies, advertising companies, trade unions, consumer groups, and social influencers are a few examples of secondary stakeholders. Finally, groups with no direct involvement (or less involvement than secondary stakeholders) in any part of the AI process and who are affected indirectly, more so than secondary stakeholders, by the AI product are referred to as tertiary stakeholders. Examples here include business competitors, local communities, and continental unions such as the African Union (AU).

\begin{tabular}{|l|l|l|}
\hline Stakeholder & Definition & Examples \\
\hline Primary & $\begin{array}{l}\text { Direct input in AI process } \\
\text { Directly impacted by developed } \\
\text { AI technology }\end{array}$ & $\begin{array}{l}\text { Investors, Customers, Company owners, } \\
\text { Employees, Vendors }\end{array}$ \\
\hline Secondary & $\begin{array}{l}\text { Indirect input in AI process } \\
\text { Indirectly impacted by } \\
\text { developed AI technology }\end{array}$ & $\begin{array}{l}\text { Regulatory agencies, Advertising companies, } \\
\text { Consumer groups, Social media influencers }\end{array}$ \\
\hline
\end{tabular}




\begin{tabular}{|l|l|l|l|}
\hline \multirow{4}{*}{ Tertiary } & $\begin{array}{l}\text { Tangential (or no) input in AI } \\
\text { process } \\
\text { Tangentially impacted by } \\
\text { developed AI technology }\end{array}$ & $\begin{array}{l}\text { Community groups, Competitors, Continental } \\
\text { Unions }\end{array}$ \\
\hline
\end{tabular}

Table 1 : Definition and examples of stakeholders in the Al ecosystem based on their proximity to the center of influence and impact in an Al project.

Stakeholder analysis is used to : (i) explain why some managers identify some groups as stakeholders, (ii) explain the effects of management decisions on different stakeholders, (iii) identify which groups have valid claims on the firm, (iv) explain how stakeholder analysis can help the firm attain its goals, (v) optimize relationships between stakeholders, and (vi) identify which groups may determine the future direction of a company (Donaldson \& Preston, 1995, pp. 65-91; Mitchel, Agle, \& Wood, 1997, pp. 853-886; Wheeler \& Sillanpaa, 1998, pp. 201-210; Freeman R. , 2001, pp. 38-48). To ensure that this framework may be effectively utilized for the above listed functions, it is imperative that parties within the AI ecosystem are identified at a granular level. We, therefore, further delineate the parties in the above three categories on the basis of the three basic stakes : fair economic opportunity, legitimacy and political equality, and authenticity.

\begin{tabular}{|c|c|c|}
\hline Stakeholder & Basic Stake & Normative Claims Basis \\
\hline Capitalists & $\begin{array}{ll}\text { Fair } & \text { Economic } \\
\text { Opportunity } & \end{array}$ & Fiscal impact \\
\hline Beneficiaries & $\begin{array}{ll}\text { Fair } & \text { Economic } \\
\text { Opportunity } & \end{array}$ & Fiscal impact \\
\hline Regulators & $\begin{array}{l}\text { Legitimacy and Political } \\
\text { Equality }\end{array}$ & Law, policies and regulations that govern AI \\
\hline Activists & $\begin{array}{l}\text { Legitimacy and Political } \\
\text { Equality }\end{array}$ & $\begin{array}{l}\text { Equal political rights and adherence to established } \\
\text { laws and regulations }\end{array}$ \\
\hline Authenticators & Authenticity & $\begin{array}{l}\text { Established mores and values in the development } \\
\text { process and adoption of AI }\end{array}$ \\
\hline Advocates & Authenticity & Adherence to established community mores and values \\
\hline
\end{tabular}

Table 2 : Stakeholders categorized in terms of the normative claims they can make in the Al ecosystem.

Primary stakeholders with normative claims on the basis of fair economic opportunity, i.e., whether the activities conducted within the AI ecosystem fiscally contribute to a common good or adversely affect one or more of the stakeholders (Reed, 2002, pp. 166 207), are either primary capitalists or primary beneficiaries. Those parties that input resources (time, labor, funds, equipment, etc.) into and expect a share of the monetary gains from an AI project are referred to as primary capitalists ; groups fiscally impacted by their use of an AI platform are primary beneficiaries. Examples of the former 
include AI developers, investors, and company owners. A medical facility that experiences increased revenue from using an AI application would fall into the latter category.

Primary stakeholders may also make claims on the system on the basis of legitimacy and political equality. Stakeholders that create laws and policies or issue regulations that govern AI legitimacy, i.e., conformity to the law or rules of the nation, are primary regulators. Legislative bodies and regulatory agencies, for example. Similarly, citizens may make claims on the AI ecosystem on the basis of political equality. The general populace should have the opportunity, space and means, to participate in discourse that is the basis for legislation enacted to govern AI ; this is vital as it is the citizens who will bear the brunt of any disruptions, political or civic, brought on by AI. The individuals or communities whose political and civil rights are impacted by changes in the political climate from AI adoption are referred to as primary activists.

Finally, primary stakeholders can make claims of authenticity on the system owing to established non - business relationships, shared values and community norms. AI developers, for example, as employees of an AI company may make claims of authenticity against the company based on its prior espoused ethos, mission statement, company codes or established corporate culture. Local communities that utilize a particular AI platform can also make claims of authenticity on the AI system. They may expect the functions of the AI platform to conform to established social and cultural norms. Those groups with direct input in the AI development and adoption process, who may make claims on the system on the basis of authenticity, are referred to as primary authenticators, while those whose expectations are that the functions and use of the AI technology they adopt will conform to established relationships and/or cultural and social mores are referred to as primary advocates.

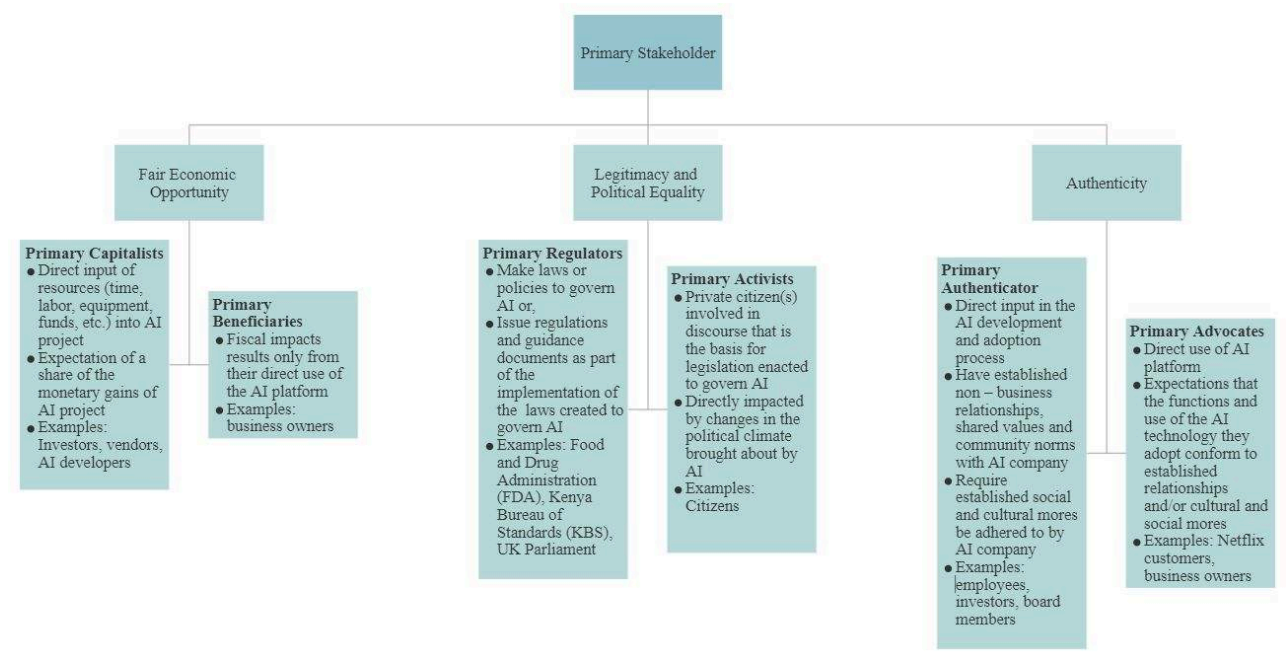

Figure 3 : Types of primary stakeholders delineated on the basis of the normative claim they make on the Al system.

Unlike the primary capitalists, secondary capitalists are only indirectly involved in the AI development and adoption process - the HR department in an AI company, for example - and are indirectly impacted by the product. Tertiary capitalists, meanwhile do not make any decisions regarding the AI project but still influence it and the bottom line of the company, e.g., Netflix users. Stakeholders whose economic prospects are indirectly impacted by the use of an AI platform by external parties but who don't 
contribute resources to the AI project are referred to as secondary beneficiaries; a pharmacy with increased sales as a result of a diagnostic and prescriptive medical AI platform used by the community would be an example. Tertiary beneficiaries' economic prospects are more indirectly impacted by an AI platform than the secondary stakeholders, e.g., business competitors. The financial fortunes of the competing company may be tied, inversely or directly, to the AI company. Their claim is of fair economic opportunity and consists of the simple demand that rival corporations compete fairly.

Secondary stakeholders make claims on the system based on their political and civil rights and the system's legitimacy. They are not, however, directly involved in crafting legal or regulatory frameworks to govern AI nor are they directly impacted by changes in the political sphere brought on by AI adoption. Parties in this category fall under two groups: (i) those who ensure laws and policies governing the AI process and product are adhered to, and (ii) those who advocate on behalf of groups whose political and civil rights are directly affected by adoption of a particular AI platform. Those in the former group are secondary regulators and the latter are secondary activists. FDA inspectors are an example of secondary regulators while lawyers are an example of secondary activists. Tertiary regulators are often involved in ventures (lobbying, for example) that aid primary regulators in crafting the laws and policies that govern AI. Groups who aid organizations or individuals that advocate on behalf of those whose political and civil rights are affected by adoption of a particular AI platform are tertiary activists. Examples of tertiary regulators include lobbyists, while a defense fund group - a group that raises funds to pay defense lawyers on behalf of a community or individual - is an example of a tertiary activist.

Secondary authenticators are groups with indirect input in the AI development and adoption process that may make claims on the system on the basis of authenticity. These groups can hold the AI company and product accountable based on mission statements, established relationships, or previously declared claims. Consumer protection agencies are an example of secondary authenticators. Communities who do not adopt (nor are they necessarily impacted by) AI technology may still make claims of authenticity on the ecosystem. AI companies may form non - business relationships with communities via advertising campaigns, PR events, local town hall forums, etc.; these relationships can then obligate the company to conform to the values established between them and the community. These groups are secondary advocates. Tertiary authenticators influence the AI development and adoption process. Consumers, for example, even those who do not use an AI platform, may have expectations on how it is produced: without the use of child labor, in a sustainable manner, employing the local labor force, etc., and may demand that the AI company meet these expectations. Tertiary advocates are groups that are only tangentially or are not impacted by AI but still make claims of authenticity on the system. An example of tertiary advocates would be regional organizations such as the African Union (AU), European Union (EU) or the United Nations (UN), who expect member states to act in accordance to the values, policies and mandates set out by the organization. The $\mathrm{AU}$, for example, may require that AI technology developed in member states propel the stated development goals of the region.

30 Identifying these stakeholders in such a granular manner helps in identifying the interests, responsibilities and accountability of each group within the AI ecosystem. It 
also ensures that each voice within this ecosystem is considered (and that none are amplified over the other) and that the power dynamics, intersecting interests, biases and informational asymmetries between these interconnected and interdependent groups are identified. This in turn will aide in creating and AI ecosystem on the African that is equitable to and inclusive of everyone.

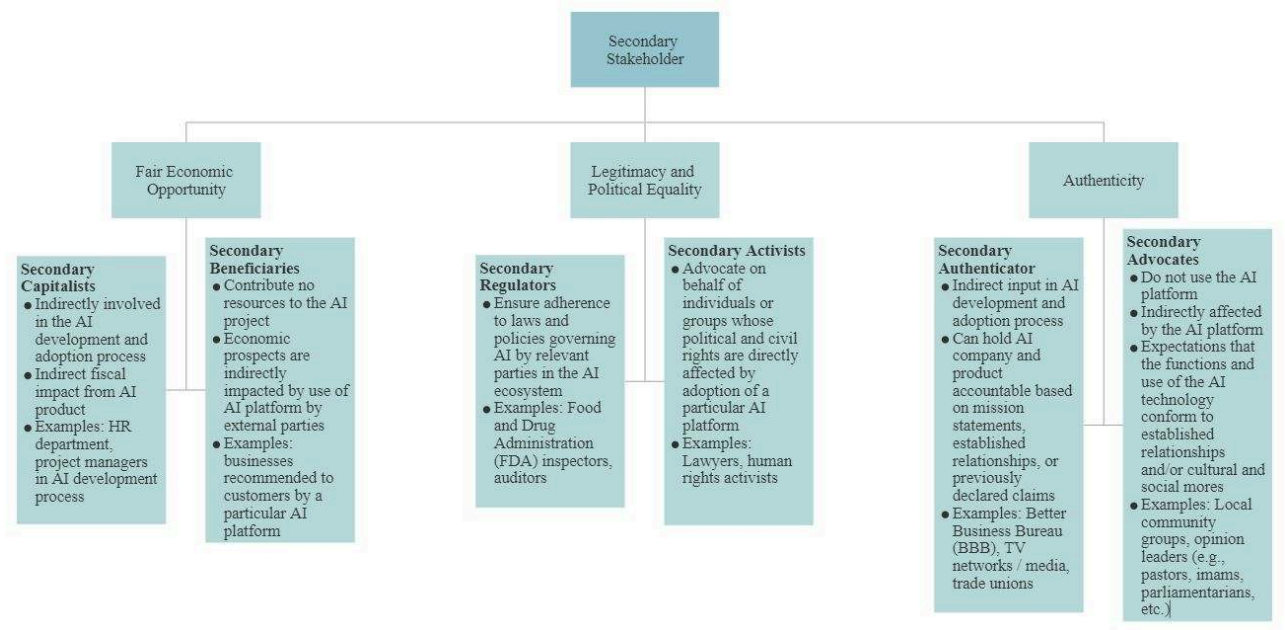

Figure 4 : Types of secondary stakeholders delineated on the basis of the normative claim they make on the Al system.

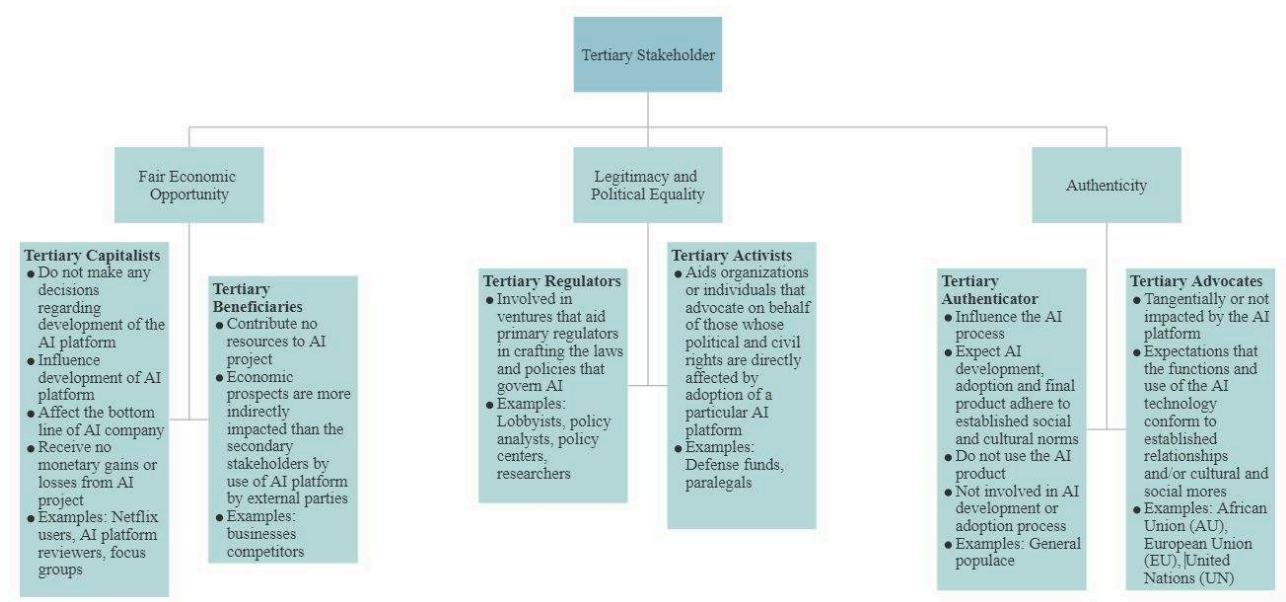

Figure 5 : Types of tertiary stakeholders delineated on the basis of the normative claim they make on the Al system

31 There are limitations to the stakeholder framework outlined above: (i) it does not address how to tackle power asymmetries between stakeholders, (ii) it does not detail how to address conflicting interests between stakeholders, and (iii) it does not account for the differences in the power of influence and impacts of stakeholders. These are complex issues and are more effectively addressed on a case by case basis.

\section{Conclusion}

In order for Africa to reap maximum benefits from AI technology, while minimizing any negative impacts, we must critically analyze the developing ecosystem from an African perspective. The AI Stakeholder framework outlined in this paper is a crucial first step in this process. This framework is currently being utilized in AI research 
projects conducted by this group to identify stakeholders of interest in specific studies. For example, in a study dealing with gender disparity in the African AI workforce, the framework outlined above was used to determine the stakeholders who bear the greater responsibility for this disparity, e.g., owners - primary capitalists versus hiring managers - secondary capitalists, and those who bear the brunt of this disparity. Similarly, projects dealing with AI in the Kenyan agricultural sector are utilizing this framework to identify the primary AI stakeholders in this sector, their responsibilities and stakeholders that should hold them accountable. There is also a study applying various Ethical Frameworks created by different institutions to govern AI to the Stakeholder framework to elucidate the responsibilities of each stakeholder group.

Further work must be done to characterize the interactions, interests, responsibilities and accountability of the stakeholders' outlined in this framework. Future projects will also determine the policies and programs that need to be created and implemented to create an equitable AI ecosystem on the continent.

\section{BIBLIOGRAPHY}

Abràmoff, M., Garvin, M., \& Sonka, M. (2010). Retinal imaging and image analysis. IEEE Reviews in Biomedical Engineering, 3, 169 - 208.

Adenle, A. A., Wedig, K., \& Azadi, H. (2019). Sustainable agriculture and food security in Africa : The role of innovative technologies and international organizations. Technology in Society, 58, 101143.

Aira. (2017). (Aira Tech Corp) Retrieved August 26, 2020, from https://aira.io/

Apodytes. (2019). Retrieved from Apodytes : https://www.apodytes.com/

Arifu. (2020). (Arifu) Retrieved August 26, 2020, from https://www.arifu.com/

Bolukbasi, T. C. (2016). Man is to Computer Programmer as Woman is to Homemaker ? Debiasing Word Embeddings. . arXiv preprint , arXiv :1607.06520.

Bryson, J. (1995). Strategic Planning for Profit and Non - Profit Organization. San Francisco : Jossey - Bass.

Buchholz, R., \& Rosenthal, S. (2005). Toward a Contemporary Conceptual Framework for Stakeholder Theory. Journal of Business Ethics, 58, 137 - 148.

Buolamwini, J., \& Gebru, T. (2018). Gender Shades : Intersectional Accuracy Disparities in Commercial Gender Classification. Proceedings of Machine Learning Research, 81, 1 - 15.

Cincotta, R. (2010, August 25). The Future of Sub-Saharan Africa's Tentative Fertility Decline. Retrieved December 8, 2020, from https://www.newsecuritybeat.org/2010/08/the-future-of-subsaharan-africas-tentative-fertility-decline/\# : :text =In \%20her \%20recent \%20post \%20on,Data \%20Sheet \%20 \%E2 \%80 \%94 \%20forecasts \%20an \%20unrealistically 
Dastin, J. (2018, October 11). Amazon scraps secret AI recruiting tool that showed bias against women. Retrieved from Reuters : https://www.reuters.com/article/us-amazon-com-jobsautomation-insight-idUSKCN1MK08G

Dews, F. (2019, January 18). Charts of the Week : Africa's changing demographics. Retrieved from Brookings Now : https://www.brookings.edu/blog/brookings-now/2019/01/18/charts-of-theweek-africas-changing-demographics/

Donaldson, T., \& Preston, L. (1995). The Stakeholder Theory of the Corporation : Concepts, Evidence, and Implications. The Academy of Management Review, 20(1), 65 - 91.

Donaldson, T., \& Preston, L. (1995). The Stakeholder Theory of the Corporation : Concepts, Evidence, and Implications. The Academy of Management Review, 20(1), 65 - 91.

Evans, O. (2019). Digital politics : internet and democracy in Africa. Journal of Economic Studies, 46(1), 169 - 191.

Feldstein, S. (2019). The Global Expansion of AI Surveillance. Washington, DC : Carnegie Endowment for International Peace.

Freeman, R. (1984). Strategic Management : a Stakeholder Approach (Pitman Series in Business and Public Policy). New York City : Harpercollins College Div.

Freeman, R. (1994). The Politics of Stakeholder Theory. Business Ethics Quarterly, 4, 409 - 421.

Freeman, R. (2001). A Stakeholder Theory of the Modern Company. Perspectives in Business Ethics Sie, 3(144), 38 - 48.

Freeman, R., \& Reed, D. (1983). Stockholders and Stakeholders : A New Perspective on Corporate Governance. California Management Review, 25(3), 88 - 106.

Goldberg, P. (2015). Trade and Inequality. Camberely : Edward Elger.

Gradely. (2020). (Gradely NG. Limited) Retrieved August 26, 2020, from https://gradely.ng/

Harrison, A., McLaren, J., \& McMillan, M. (2011). Recent Perspectives on Trade and Inequality. Annual Review of Economics, 3(1), 261 - 289.

Helpicto. (n.d.). (Equidex) Retrieved August 26, 2020, from Helpicto : http://www.helpicto.com/ en/home-2/

Hendry, J. (2001). Missing the target : Normative stakeholder theory and the corporate governance debate. Business Ethics Quarterly, 11(1), 159 - 176.

I.O.F Standardization. (2009). Managing for the sustained success of an organization - A quality management approach. International Organization for Standardization.

I.O.F Standardization. (2012). ISO 21500 :2012 Guidance on Project Management. International Organization for Standardization.

Insights, G. D. (2019). Digital 2019 Q3 Global Digital Statshot Report. DataReportal.

Kidaptive. (2020). (Kidaptive) Retrieved August 26, 2020, from Kidaptive : https:// www.kidaptive.com/

Kubota, T. (2017). Stanford Medicine. Retrieved August 26, 2020, from https://med.stanford.edu/ news/all-news/2017/11/algorithm-can-diagnose-pneumonia-better-than-radiologists.html. 2018 August 25 
Kusakana, K. (2014). A survey of innovative technologies increasing the viability of microhydropower as a cost effective rural electrification option in South Africa. Renewable and Sustainable Energy Reviews, 37, 370-379.

Lagakos, D. (2020). Urban-Rural Gaps in the Developing World : Does Internal Migration Offer Opportunities? Journal of Economic Perspectives, 34(3), $174-192$.

Larson, J., Mattu, S., Kirchner, L., \& Angwin, J. (2016, May 23). How We Analyzed the COMPAS Recidivism Algorithm. Retrieved from ProPublica : https://www.propublica.org/article/how-weanalyzed-the-compas-recidivism-algorithm

Linn, A. (2018, August 25). How Microsoft Computer Scientists and Researchers are Working to 'Solve' Cancer. Retrieved August 26, 2020, from Microsoft : https://news.microsoft.com/stories/ computingcancer

Marable, M. (2015). How capitalism underdeveloped Black America : Problems in race, political economy, and society. Chicago : Haymarket Books.

Microsoft AI. (2019). (Microsoft Company) Retrieved August 26, 2020, from https:// www.microsoft.com/en-us/ai/seeing-ai

Microsoft Translator. (2019). (Microsoft Company) Retrieved August 26, 2020, from https:// translator.microsoft.com/

Mitchel, R., Agle, B., \& Wood, D. (1997). Towards a Theory of Stakeholder Identification and Salience : Defining the Principle of Who and What Really Counts. Academy of Management Review, 22(4), 853 - 886.

M-Shule. (2018). Retrieved August 26, 2020, from https://m-shule.com/

Mubila, M. (2012). Briefing Notes for AfDB's Long-Term Strategy : Africa's Demographic Trends. Africa Development Bank Group.

Obermeyer, Z., Powers, B., Vogeli, C., \& Mullainathan, S. (2019). Dissecting racial bias in an algorithm used to manage the health of populations. Science, 366(4646), $447-453$.

PriceWaterhouseCoopers. (2017). Sizing the Prize : What's the Real Value of AI for Your Business and How Can You Capitalise? PriceWaterhouseCoopers.

Querium. (2013). (Querium) Retrieved August 26, 2020, from Querium : http://querium.com/

Reed, D. (1999). Stakeholder Management Theory : A Critical Theory Perspective. Business Ethics Quarterly, 9(3), 453 - 483.

Reed, D. (2002). Employing Normative Stakeholder Theory in Developing Countries A Critical Theory Perspective. Business and Society, 41(2), 166 - 207.

Standford Research Center. (1963). Internal Memorandum. Stanford Research Center.

Traxler, J., \& Leach, J. (2006). Innovative and sustainable mobile learning in Africa. Fourth IEEE International Workshop on Wireless, Mobile and Ubiquitous Technology in Education (WMTE'06) (pp. 98 - 102). Athens : IEEE.

Ubenwa. (n.d.). (Ubenwa Health) Retrieved August 26, 2020, from www.ubenwa.ai

Ubenwa. (2020, August 26). Retrieved from Ubenwa Health : www.ubenwa.ai

Udomkun, P., Wiredu, A. N., Nagle, M., Müller, J., Vanlauwe, B., \& Bandyopadhyay, R. (2017). Innovative technologies to manage aflatoxins in foods and feeds and the profitability of application-A review. . Food Control, 76, 127 - 138. 
United Nations and Economic Commission of Africa. (2016). The Demographic Profile of African Countries. Economic Commission of Africa.

West, D. (2018). The Future of Work : Robots, AI, and Automation. Brookings Institution Press.

Wheeler, D., \& Sillanpaa, M. (1998). Including the stakeholders : The business case. Long Range Planning, 31(2), 201-210.

Wijnberg, N. M. (2000). Normative stakeholder theory and Aristotle : The link between ethics and politics. Journal of Business Ethics., 25(4), 329 - 342.

World Bank Group. (2018). World Development Report : Learning to Realize Educations Promise. Washington, DC, USA : International Bank for Reconstruction and Development / The World Bank.

\section{ABSTRACTS}

Development and adoption of artificial intelligence (AI) in Africa has occurred slowly relative to developed countries. A vibrant AI ecosystem is growing on the continent. Due to the unique geographical, cultural and political nature of the continent, the $4^{\text {th }}$ industrial revolution on the continent is evolving differently from its global counterparts. The motivations for development of AI systems, the parties involved, and the impact of the AI ecosystem on the continent are therefore best analyzed and framed through a unique African lens. This paper seeks to begin this process by developing a conceptual framework to characterize the parties involved in the African AI ecosystem. i.e., the African AI stakeholder. Identification of these stakeholders will aid in determining their interests, responsibilities and accountability and will provide a basis for the development and implementation of an equitable AI ecosystem. It is our goal that this framework, ultimately, be used to guide the contributions from the African AI perspective in global dialogues on ethics, bias, inclusion and similar topics in the AI sphere.

El desarrollo y la adopción de la inteligencia artificial (IA) en África se han producido con lentitud en relación con los países desarrollados. Un vibrante ecosistema de IA está creciendo en el continente. Debido a la singular naturaleza geográfica, cultural y política del continente, la cuarta revolución industrial en el continente está evolucionando de manera diferente a sus homólogos mundiales. Por lo tanto, las motivaciones para el desarrollo de los sistemas de IA, las partes involucradas y el impacto del ecosistema de IA en el continente se analizan y enmarcan mejor a través de una lente africana única. El presente documento trata de iniciar este proceso elaborando un marco conceptual para caracterizar a las partes que intervienen en el ecosistema africano de la IA, es decir, el actor africano de la IA. La identificación de estas partes interesadas ayudará a determinar sus intereses, responsabilidades y rendición de cuentas y servirá de base para el desarrollo y la aplicación de un ecosistema de IA equitativo. Nuestro objetivo es que este marco, en última instancia, se utilice para orientar las contribuciones desde la perspectiva de la IA africana en los diálogos mundiales sobre la ética, el sesgo, la inclusión y temas similares en la esfera de la IA.

Le développement et l'adoption de l'intelligence artificielle (IA) en Afrique s'est fait lentement par rapport aux pays développés. Un écosystème d'IA dynamique se développe sur le continent. En raison de la nature géographique, culturelle et politique unique du continent, la 4e révolution industrielle sur le continent évolue différemment de ses homologues mondiaux. Les motivations du développement des systèmes d'IA, les parties impliquées et l'impact de l'écosystème de l'IA sur le continent sont donc mieux analysés et encadrés à travers une lentille africaine unique. Le présent document vise à amorcer ce processus en élaborant un cadre conceptuel permettant de 
caractériser les parties impliquées dans l'écosystème africain de l'IA, c'est-à-dire la partie prenante africaine de l'IA. L'identification de ces parties prenantes aidera à déterminer leurs intérêts, leurs responsabilités et leur obligation de rendre compte et servira de base au développement et à la mise en œuvre d'un écosystème d'IA équitable. Notre objectif est que ce cadre soit utilisé pour guider les contributions du point de vue de l'IA africaine dans les dialogues mondiaux sur l'éthique, les préjugés, l'inclusion et autres sujets similaires dans la sphère de l'IA.

\section{INDEX}

Mots-clés: IA, Afrique, Théorie normative des parties prenantes, Parties prenantes Keywords: AI, Africa, Normative Stakeholder Theory, Stakeholders

Palabras claves: IA, África, Teoría normativa de las partes interesadas, Partes interesadas

\section{AUTHORS}

\section{ANGELINE WAIREGI}

CIPIT, Strathmore University, SR. Thomas More Building, Nairobi

West, Keri Rd

\section{MELISSA OMINO}

CIPIT, Strathmore University, SR. Thomas More Building, Nairobi West, Keri Rd

\section{ISAAC RUTENBERG}

CIPIT, Strathmore University, SR. Thomas More Building, Nairobi West, Keri Rd 